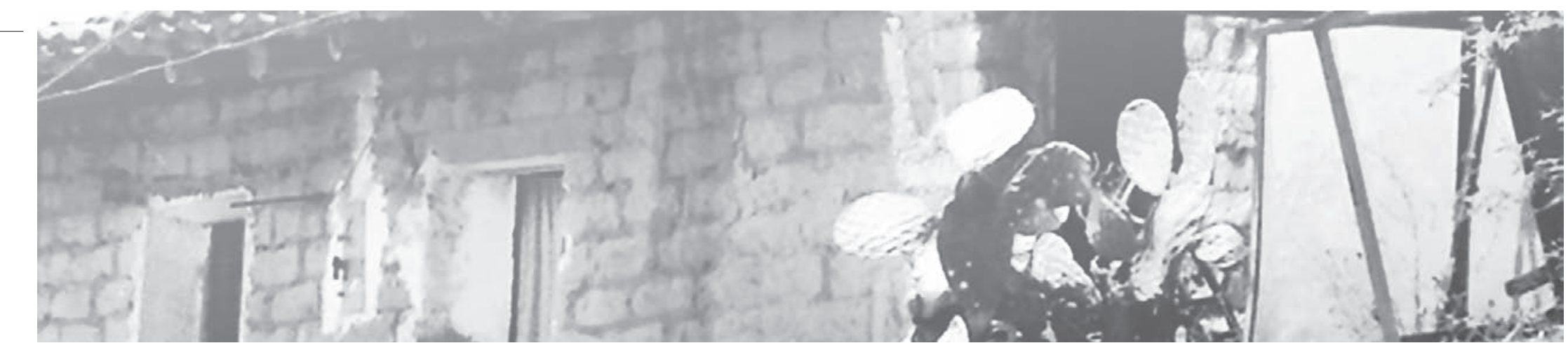

\section{REPENSAR LA PRODUCCIÓN CONTEMPORÁNEA DEL HÁBITAT, VULNERABILIDAD Y POBREZA EN LA CIUDAD}

RETHINKING
CONTEMPORARY
PRODUCTION OF HABITAT,
VULNERABILITY AND
POVERTY IN THE CITY

Today, the southern hemisphere countries are key players in the urbanization phenomenon. Many of the industrial centers that supported and shaped urbanization in the northern half of the globe during the XXth century are now "shrinking", facing financial crisis, population loss, deterioration of physical structures and sense of pessimism and abandonment in cities such as Detroit (USA), Halle (Germany) or Ivanovo (Russia). Either due to the loss of competitiveness in globalised markets oriented to car or petrochemical production, northern hemisphere cities have taken different roads: while some metropolises are still in the path of capitalism, others are not. As the shrinking 
vergentes: algunas continúan su camino iluminado por el capitalismo financiero mientras que otras se apagan lentamente. Ciertamente, al tiempo que la amenaza de achicamiento obliga a la reinvención de la urbe del Norte, en el Sur los grandes centros urbanos caminan de forma sostenida a transformarse en mega-ciudades por medio de procesos y sendas diversas y muchas de ellas aún poco exploradas.

M. Davis en Planet of Slums advierte que el planeta urbano, momento en que el hábitat urbano se posesiona como la forma mayoritaria de asentamiento a escala mundial, no está precisamente signado por las mega-infraestructuras y torres de cristal y acero que prometían las grandes metrópolis del siglo XX, sino más bien el paisaje que se replica es el de una urbanización precaria y vulnerable. Son las acciones fragmentarias, muchas veces a fuerza de emprendimientos de los propios habitantes que operan en zonas no reguladas o enmarcadas de forma insuficiente por la acción política-institucional, las que se constituyen como principales fuerzas de urbanización en amplios espacios de los continentes de Asia, África y América Latina.

La urbanización en este contexto deviene en aventura, una marcada por el riesgo y vulnerabilidad. El riesgo se asume como parte del Zeitgeist contemporáneo, tal como lo proyecta U. Beck en "La sociedad del riesgo" al advertir el debilitamiento paulatino de la capacidad de cohesión de las estructuras sociales que dotaron de seguridad y recursos de identidad process forces northern cities to reinvent themselves, southern metropolises, through different and mostly unexplored procedures, are on their way to become mega-cities.

M. Davis, in his book "Planet of Slums", warns that the urban planet -that is to say, the urban habitat at world scale- is not reflected by the mega-structures and the crystal and steel towers promised by the cities of the XXth century, but it is the expression of a vulnerable and precarious urbanization. Fragmentary actions, mainly those carried out by dwellers living in non-regulated or improperly demarcated areas, are one of the principal urbanization forces in Asia, Africa and Latin America.

In this context, urbanization becomes an undertaking marked by risk and vulnerability. Risk is part of our contemporary zeitgeist, as mentioned by Ulrich Beck in his book "Risk Society"; he mentions the weakening of the cohesive capacity of the social structures that provided safety and identity resources during most part of the history of modern society. As a result of the individualization process, people have the possibility to establish social networks in order to achieve goals. The 
durante buena parte de lo que hemos conocido como sociedad moderna. En virtud del proceso de individualización, los sujetos tienen la posibilidad progresiva de articular en torno suyo redes sociales que les permitan cumplir con sus objetivos. El sujeto es liberado a construir lo social, a buscar sus recursos de identidad e inserción en la sociedad. En efecto, la sociedad del riesgo es producto de la victoria de la versión liberal de la modernidad, que en su correlato económico se conoce como neoliberal.

La ciudad como espacio del riesgo y vulnerabilidad, pero ya no tan sólo expresión de ello, sino también como dinámica generadora. El sujeto entregado a la dimensión heroica del emprendimiento individual. De esta forma la política conservadora-liberal latinoamericana reclama el retiro enérgico del estado y exige mayores espacios para el despliegue del individuo y sus fuerzas creadoras. La maduración de la organización de los intereses privados -cuya mejor formulación sería el mercado- se encargaría desde esta perspectiva de las desigualdades y las diferencias en la ciudad, formulación que resulta en extremo ideologizada al olvidar que la teoría nunca es un reflejo de la realidad, sino más bien una representación de ella.

La vulnerabilidad en la ciudad latinoamericana se había experimentado durante su período de expansión explosiva de la segunda mitad del siglo pasado en virtud de un estado incapaz de insertar e integrar a amplios sectores de la población en mercados del individual is freed to build society, to look for identity resources and social integration. In effect, risk society is the consequence of the victory of the liberal version of modernity, which in economic terms is known as neoliberalism.

The city is not only the expression of risk and vulnerability, but also the creator of these concepts, in which the individual is focused on personal projects. In this way, Latin American conservative-liberal policies claim the withdrawal of the State and demand more spaces for people and their creative capacity. From this perspective, the development of private interests -being the market its best example- would address inequality and differences within the city; however, this view is a hypothetical scenario, as theory is not a reflection of reality, but a representation of it.

Vulnerability was experienced in Latin America during the explosive expansion that took place in the second half of the XXth century; it resulted from the incapacity of the State to insert and integrate segments of population in job markets and service networks. However, this vulnerability, from a neoliberal context, is determined by 
trabajo y redes de servicios. No obstante, en el contexto neo-liberal adopta un nuevo encuadre, marcado por la precarización del trabajo, privatización de servicios y un estado asistencialista. Interesante ejemplo provee L. Waqcuant y su re-definición del ghetto estadounidense (Marginales Urbanos - Urban Outcasts), al describir cómo estas áreas de la ciudad experimentaron en las últimas dos décadas una transformación estructural, en que devienen ya no sólo en espacios de reclusión sino también de estigmatización territorial que conduce a sus habitantes a romper sus vínculos materiales y simbólicos con el ghetto, a desmarcarse de su pertenencia y a buscar una salida individual de él. Si en algún momento del pasado los ghettos desarrollaron identidades de resistencia basadas en redes solidarias y comunitarias, hoy en día el ghetto representa un lastre para sus habitantes, quienes buscan su salida, su salvación individual. Esta es una imagen aplicable a cientos de barrios populares de la ciudades latinoamericanas que otrora mantenían una historia de lucha colectiva por la integración social y que hoy en día han devenido en territorios desconectados del resto de la ciudad y dominados por los circuitos del narcotráfico.

Parece que hemos asumido socialmente la inevitabilidad del riesgo y su vulnerabilidad asociada. Emerge entonces un campo de exploración fundamental para los estudios urbanos que se pregunta por sus construcciones en el hábitat y consecuencias para la población. El presente número 70 de precarious employment, privatization of services and a welfare-oriented State. The re-definition of the American ghetto given by Loüc Waqcuant ("Urban Outcasts") describes how some areas of the city experienced a structural transformation in two decades, becoming not only isolated places, but also stigmatized zones in which people break material and symbolic links with the ghetto in order to escape from those areas. In the past, ghettos developed resistance identities based on social and communal networks; today, these zones represent an obstacle for its dwellers, as they do not want to live in those places. This example is valid for Latin America, as there are hundreds of isolated neighborhoods dominated by drug trafficking that used to fight for social integration.

The inevitability of risk and its associated vulnerability has been socially addressed. As a result, a new field of research, fundamental for urban studies focused on habitat and population, emerges. Centered on rethinking habitat, vulnerability and poverty, this issue of Revista INVI proposes elements that contribute to the identification and description of processes that cause vulnerability and poverty in Latin American contemporary 
la Revista INVI ha tenido como propósito -bajo la invitación a repensar el hábitat, vulnerabilidad y pobreza- plantear elementos que asistan en la identificación y descripción de los procesos que producen vulnerabilidad y pobreza en la ciudad latinoamericana contemporánea, explorar en sus múltiples articulaciones que vinculan políticas públicas, aspectos medioambientales y estrategias de sobreviviencia, entre otras.

El artículo Reasentar un hábitat vulnerable. Teoría versus Praxis, de Anne-Catherine Chardon, plantea la discusión respecto a las variables que la política pública colombiana considera en la vulnerabilidad del hábitat en torno a un caso de relocalización en contexto de riesgo natural. El artículo La ciudad desde la casa: ciudades espontáneas en Lima del equipo de investigadores compuesto por Elia Sáez G., José García C. y Fernando Roch P. plantea cómo a partir de la construcción de viviendas precarias que cumplen múltiples funciones surge también una estrategia para la construcción de ciudad. El texto presentado por Carlos Muñoz P., Matías Antonio Dziekoński R., Gabriela Soto V. y Ninoska Lamilla, Hábitat y territorio: Coherencia para el ordenamiento territorial. El caso de la provincia de Colchagua, Chile, plantea la siempre compleja aplicación de instrumentos de planificación territorial y sus articulaciones con intereses ciudadanos en contextos en que el estado carece de una política -en apariencia- coherente para la gestión del territorio. La injerencia de aspectos cities, as well as exploring the different aspects that relate public policies, environment and survival strategies, among others.

The article Resettling a Vulnerable Habitat. Theory against Practice, written by AnneCatherine Chardon, proposes a discussion on how Colombian authorities address the vulnerability of habitat when it comes to relocating populations threatened by natural hazards.

The article Growing Cities from Houses: Spontaneous Cities in Lima, written by Elia Saez G., José García C. and Fernando Roch P., addresses how strategies for city construction emerge from the building of precarious housing. Carlos Muñoz P., Matías Antonio Dziekoński R., Gabriela Soto V. and Ninoska Lamilla, in Habitat and Territory: Coherent Town Planning, the Case of Colchagua Province, Chile, analyze the complex implementation of instruments for town planning and their relation with citizen interests in contexts where the State lacks policies for land management. By presenting little explored areas regarding urban vulnerability, the article Climate Change and Urban Climate: a Relationship between 
medioambientales en la configuración de las desigualdades en la ciudad son trabajados en el artículo Cambios climáticos y climas urbanos: Relaciones entre zonas termales y condiciones socioeconómicas de la población de Santiago de Chile, publicado por Hugo Romero, Marcela Salgado y Pamela Smith, presentando dimensiones poca exploradas para el estudio de la vulnerabilidad urbana.

Adicionalmente, el número 70 de Revista INVI incluye el artículo La recogida de basura en Megaciudades: En el marco de la sostenibilidad, de Fabian Tron, que plantea la complementariedad de prácticas formales e informales en ciudades complejas para el reciclaje de residuos, tomando atención en la complementación de lo informal y lo formal para la eficiencia de los sistemas urbanos. Cierra el presente número la reseña de Carlos Lange V. del libro La Doctrina del Shock. El Auge del Capitalismo del Desastre, de Naomi Klein, un ensayo muy pertinente en el contexto post-terremoto de Chile, que sugiere la tesis de cómo a partir de contextos de catástrofes naturales y sociales se promueve el retiro del estado y ampliación del espacio de operación del capital privado.

Estamos seguros que los escritos presentados en este número serán un aporte relevante a la discusión regional sobre los mecanismos de producción de vulnerabilidad y pobreza en el Hábitat contemporáneo.

Walter Imilan $\mathrm{O}$.
Thermal Zones and the Socioeconomic Conditions of the Population of Santiago de Chile, written by Hugo Romero, Marcela Salgado and Pamela Smith, analyses the influence of environmental aspects on the configuration of inequality within the city.

Additionally, this issue of Revista INVI includes the article Waste Collection in Mega-Cities: Within the Framework of Sustainability, written by Fabian Tron. This article analyses the complementarity of formal and informal practices in complex cities regarding waste recycling and the efficiency of urban systems. Finally, Carlos Lange V. reviews the book "The Shock Doctrine: The Rise of Disaster Capitalism", written by Naomi Klein, a relevant essay in the post-earthquake context that suggests the thesis of the withdrawal of the State and the increase of private participation as a result of natural and social catastrophes.

We are sure these articles will contribute to the regional debate on the mechanisms of vulnerability and poverty production in contemporary habitat.

Walter Imilan $O$. 